Nevada

Environmental

Restoration

Project

\title{
Corrective Action Plan for Corrective Action Unit 151: Septic Systems and Discharge Area, Nevada Test Site, Nevada
}

Controlled Copy No::

Revision: 0

March 2007

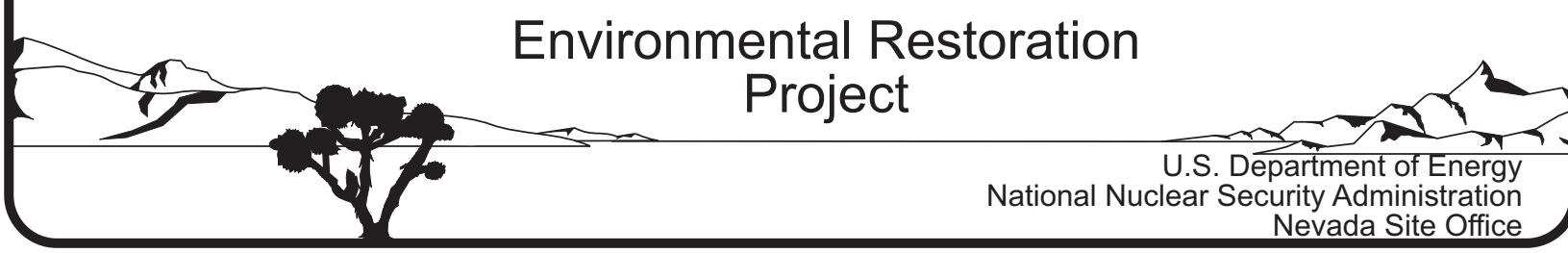




\title{
DISCLAIMER
}

Reference herein to any specific commercial product, process, or service by trade name, trademark, manufacturer, or otherwise, does not necessarily constitute or imply its endorsement, recommendation, or favoring by the United States Government or any agency thereof or its contractors or subcontractors.

This report has been reproduced directly from the best available copy.

Available for sale to the public from:

\author{
U.S. Department of Commerce \\ National Technical Information Service \\ 5285 Port Royal Road \\ Springfield, VA 22161-0002 \\ Telephone: (800) 553-6847 \\ Fax: (703) 605-6900 \\ E-mail: orders@ntis.gov \\ Online ordering: http://www.ntis.gov/ordering.htm
}

Available electronically at http://www.osti.gov/bridge.

Available for a processing fee to the U.S. Department of Energy and its contractors, in paper, from:

\author{
U.S. Department of Energy \\ Office of Scientific and Technical Information \\ P.O. Box 62 \\ Oak Ridge, TN 37831-0062 \\ Telephone: (865) 576-8401 \\ Fax: (865) 576-5728 \\ E-mail: reports@adonis.osti.gov
}




\title{
CORRECTIVE ACTION PLAN \\ FOR CORRECTIVE ACTION UNIT 151: SEPTIC SYSTEMS AND DISCHARGE AREA NEVADA TEST SITE, NEVADA
}

\author{
U.S. Department of Energy \\ National Nuclear Security Administration \\ Nevada Site Office \\ Las Vegas, Nevada
}

Controlled Copy No.

Revision: 0

March 2007 
THIS PAGE INTENTIONALLY LEFT BLANK 


\section{CORRECTIVE ACTION PLAN FOR CORRECTIVE ACTION UNIT 151: SEPTIC SYSTEMS AND DISCHARGE AREA NEVADA TEST SITE, NEVADA}

Peter A. Sanders,

Acting Federal Sub-Project Director

Industrial Sites Sub-Project

Approved By: SIGNATURE APPROVED

Kevin J. Cabble,

Acting Federal Project Director

Environmental Restoration Project 
THIS PAGE INTENTIONALLY LEFT BLANK 


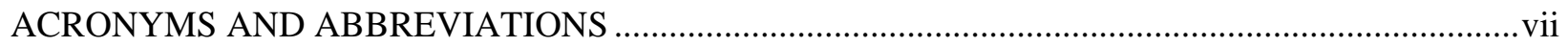

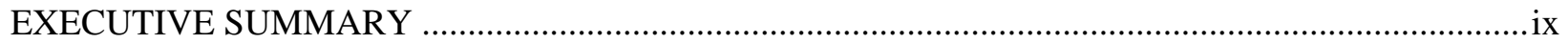

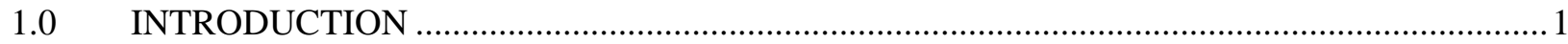

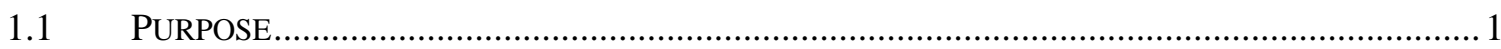

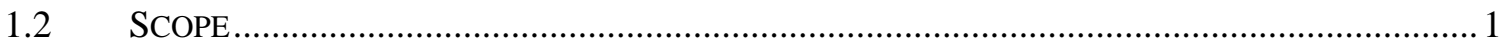

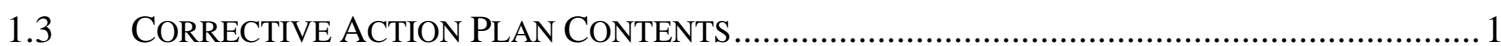

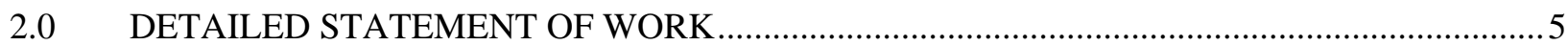

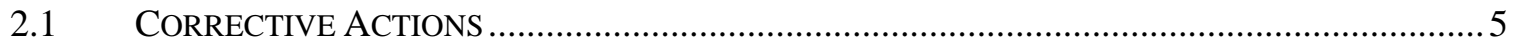

2.1.1 Alternative 1, No Further Action ........................................................................ 5

2.1.1.1 Corrective Action Site 02-05-01, UE-2ce Pond .................................... 5

2.1.1.2 Corrective Action Site 12-03-01, Sewage Lagoons (6) ........................ 5

2.1.1.3 Corrective Action Site 12-04-01, Septic Tanks (System \#4)................ 8

2.1.1.4 Corrective Action Site 12-04-02, Septic Tanks .................................... 8

2.1.1.5 Corrective Action Site 12-04-03, Septic Tank .................................11

2.1.1.6 Corrective Action Site 12-47-01, Wastewater Pond........................... 11

2.1.1.7 Corrective Action Site 18-03-01, Sewage Lagoon ............................. 11

2.1.1.8 Corrective Action Site 18-99-09, Sewer Line (Exposed) ................... 15

2.1.2 Alternative 2, Clean Closure............................................................................ 15

2.1.2.1 Corrective Action Site 12-04-01, Septic Tanks (System \#1)............. 15

2.1.3 Alternative 3, Close in Place with Administrative Controls ................................ 17

2.1.3.1 Corrective Action Site 12-03-01, Sewage Lagoons (6) (Lagoon A). 17

2.2 CONSTRUCTION QUALITY ASSURANCE/QUALITY CONTROL ........................................ 17

2.2.1 Construction Field Sample Collection Activities ................................................ 17

2.2.2 Construction Laboratory/Analytical Data Quality Indicators ............................... 17

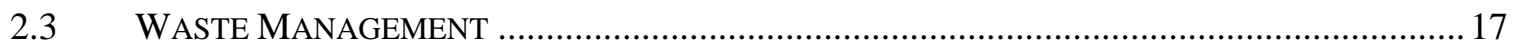

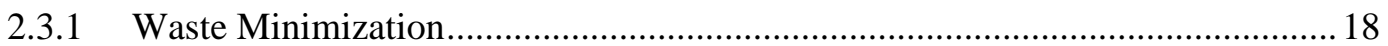

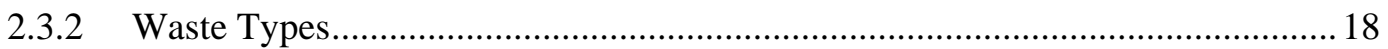

2.3.2.1 Sanitary Waste and Construction Debris ............................................ 18

2.3.2.2 Low-Level Waste ............................................................................. 18

2.3.2.3 Hazardous Waste ............................................................................ 18

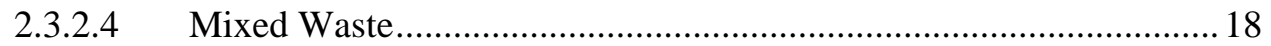

2.3.2.5 Toxic Substances Control Act-Regulated Waste ................................ 19

2.3.2.6 Decontamination Waste................................................................. 19

2.3.2.7 Personal Protective Equipment........................................................... 19

2.4 CONFIRMATION OF CORRECTIVE ACTIONS................................................................. 19

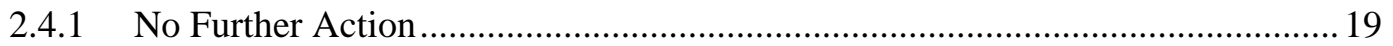

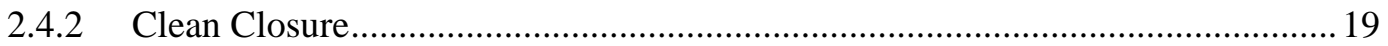

2.4.3 Close in Place with Administrative Controls ........................................................ 19

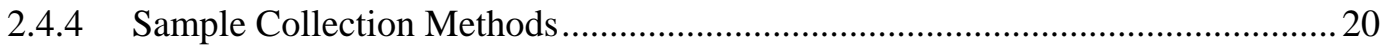

2.4.5 Laboratory/Analytical Data Quality Indicators ................................................... 20

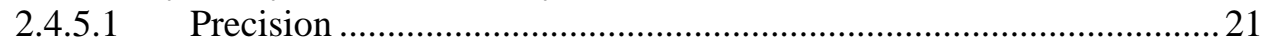

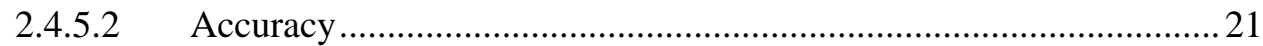

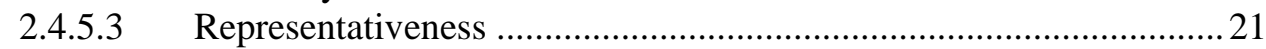

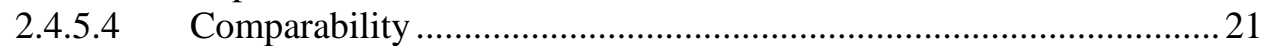

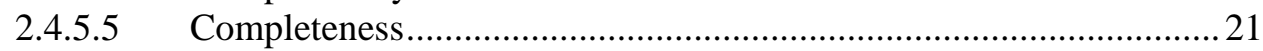

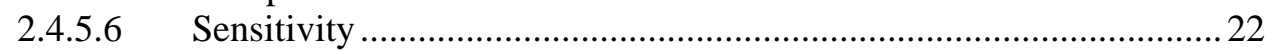

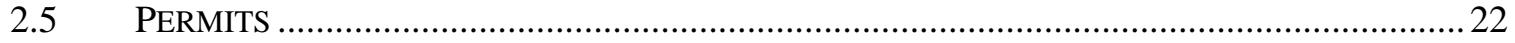


2.5.1 National Environmental Policy Act Checklist ................................................ 22

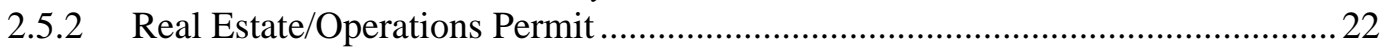

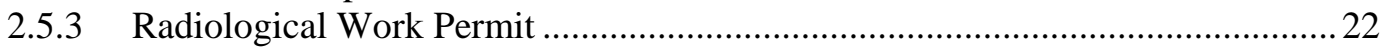

2.5.4 Utility Clearances, Excavation Permits, and Blind Penetration Permits .............. 22

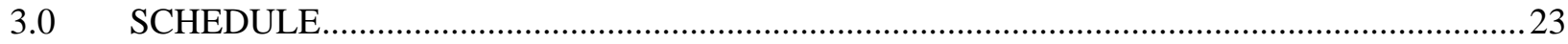

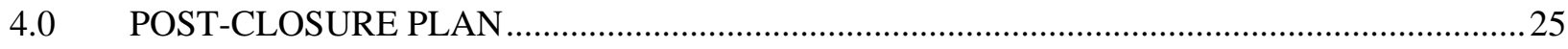

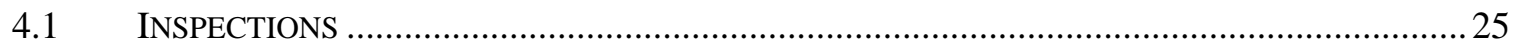

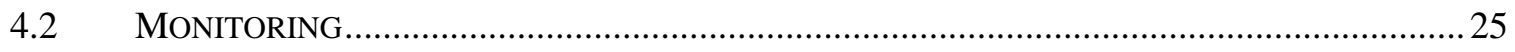

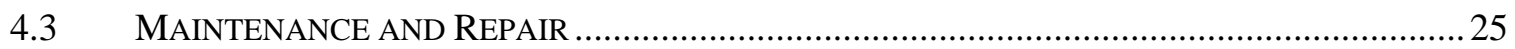

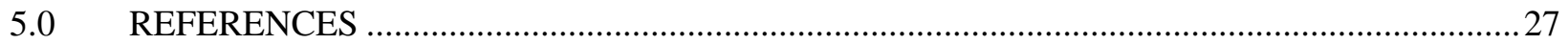

LIBRARY DISTRIBUTION LIST

\section{LIST OF FIGURES}

Figure 1. Corrective Action Unit 151 Site Location Map .............................................. 2

Figure 2. Corrective ACtion Site 12-03-01, SEWAGE Lagoons (6).................................... 6

Figure 3. Area 12 Corrective Action Sites Location MAP ............................................... 7

Figure 4. Corrective ACTION Site 12-04-01, SEPTIC TANKS (SYSTEM \#4) ............................. 9

Figure 5. Corrective ACtion Site 12-04-02, SEPTIC TANKS (SYSTEM \#5) ............................ 10

Figure 6. Corrective Action Site 12-04-03, SePtic TANK (SYSTEM \#3)............................... 12

Figure 7. Corrective ACTION Site 12-47-01, WASTEWATER POND ...................................... 13

Figure 8. Corrective Action Site 18-03-01, SEWAGE LAGOON........................................... 14

Figure 9. Corrective Action Site 12-04-01, SEPTIC TANKS (SySTEM \#1) ............................ 16

\section{LIST OF TABLES}

Table 1. Corrective Action Unit 151 Closure Activities ............................................... 3

TABle 2. Corrective Action Site 12-04-01 (System \#1) Characterization Summary .... 15

\section{LIST OF APPENDICES}

APPENDIX A.1. ENGINEERING SPECIFICATIONS AND DRAWINGS......................................... A.1-1

APPENDIX A.2. SAMPLING AND ANALYSIS PLAN ......................................................... A.2-1

ApPENDix A.3. Project ORGANIZATIOn............................................................................. A.3-1 


\section{ACRONYMS AND ABBREVIATIONS}

\begin{tabular}{|c|c|}
\hline BMP & best management practice \\
\hline $\mathrm{BN}$ & Bechtel Nevada \\
\hline CADD & Corrective Action Decision Document \\
\hline CAIP & Corrective Action Investigation Plan \\
\hline CAP & Corrective Action Plan \\
\hline CAS & Corrective Action Site \\
\hline CAU & Corrective Action Unit \\
\hline $\mathrm{CD}$ & Company Directive \\
\hline COC(s) & contaminant(s) of concern \\
\hline CR & Closure Report \\
\hline DOE & U.S. Department of Energy \\
\hline DQI & Data Quality Indicator \\
\hline DQO & Data Quality Objective \\
\hline EPA & U.S. Environmental Protection Agency \\
\hline FAL & Final Action Level \\
\hline FFACO & Federal Facility Agreement and Consent Order \\
\hline FIMS & Facilities Information Management System \\
\hline HW & hazardous waste \\
\hline in. & inch(es) \\
\hline LLW & low-level waste \\
\hline MW & mixed waste \\
\hline NDEP & Nevada Division of Environmental Protection \\
\hline NEPA & National Environmental Policy Act \\
\hline NNSA/NSO & $\begin{array}{l}\text { U.S. Department of Energy, National Nuclear Security Administration } \\
\text { Nevada Site Office }\end{array}$ \\
\hline NNSA/NV & $\begin{array}{l}\text { U.S. Department of Energy, National Nuclear Security Administration } \\
\text { Nevada Operations Office }\end{array}$ \\
\hline NSTec & National Security Technologies, LLC \\
\hline NTS & Nevada Test Site \\
\hline OI & Organization Instruction \\
\hline $\mathrm{OP}$ & Organization Procedure \\
\hline PAL & preliminary action level \\
\hline
\end{tabular}




\section{ACRONYMS AND ABBREVIATIONS (CONTINUED)}

PRG preliminary remediation goal

$\% \mathrm{R}$

percent recovery

PCBs

polychlorinated biphenyls

PPE

personal protective equipment

QA/QC

Quality Assurance/Quality Control

RPD

relative percentage difference

REOP

Real Estate/Operations Permit

RWP

Radiological Work Permit

SVOC

semi-volatile organic compound

TCLP

toxicity characteristic leaching procedure

TPH

total petroleum hydrocarbons

TSCA

Toxic Substances Control Act

UR

use restriction

VCP

vitrified clay pipe

VOC

volatile organic compound

WGS

Waste Generator Services 
Corrective Action Unit (CAU) 151, Septic Systems and Discharge Area, is listed in the Federal Facility Agreement and Consent Order (FFACO) of 1996 (FFACO, 1996). CAU 151 consists of eight Corrective Action Sites (CASs) located in Areas 2, 12, and 18 of the Nevada Test Site (NTS), which is located approximately 65 miles northwest of Las Vegas, Nevada. CAU 151 consists of the following CASs:

- CAS 02-05-01, UE-2ce Pond

- CAS 12-03-01, Sewage Lagoons (6)

- CAS 12-04-01, Septic Tanks

- CAS 12-04-02, Septic Tanks

- CAS 12-04-03, Septic Tank

- CAS 12-47-01, Wastewater Pond

- CAS 18-03-01, Sewage Lagoon

- CAS 18-99-09, Sewer Line (Exposed)

Site characterization of the CAU 151 CASs was performed in 2005 and the results are presented in Appendix A of the CAU 151 Corrective Action Decision Document (U.S. Department of Energy, National Nuclear Security Administration Nevada Site Office, 2006). The scope of work required to implement the recommended closure alternatives is summarized below.

- CAS 02-05-01, UE-2ce Pond, contains no contaminants of concern (COCs) above Final Action Levels (FALs). No further action is required for this site, and no work will be performed.

- CAS 12-03-01, Sewage Lagoons (6), contains no COCs above FALs for Lagoons C, D, F, and G. No further action is required for these lagoons, and no work will be performed.

Additionally, no COCs were identified for Lagoons B and E. No further action is required for these lagoons; however, as a best management practice (BMP), these areas will be recorded in the Facilities Information Management System (FIMS) database as administrative use restriction (UR) areas. No postings or post-closure monitoring will be required.

Lagoon A contains arsenic in the soil at concentrations above the FAL and will be closed in place with administrative controls. A UR will be implemented for this lagoon.

- CAS 12-04-01, Septic Tanks, contains no COCs above FALs for System \#4. No further action is required for System \#4; however, as a BMP, the liquid contents will be removed from the tanks in this system, solidified, and disposed at an appropriate disposal facility. If it is practical to remove the tanks, then sludge will be removed from the tanks in this system and disposed at an appropriate disposal facility. The tanks will then be removed and disposed at an appropriate disposal facility. The excavated areas will be backfilled with NTS native fill, and all remaining open lines from tank connections will be grouted. If it is not practical to remove the tanks due to active utilities being present within close proximity to the tanks, then sludge will not be removed from the tanks, and the tanks will be filled with inert material and left in place. 


\section{EXECUTIVE SUMMARY (continued)}

Results of the characterization reported COCs above FALs for System \#1. This system will be clean closed. The liquid contents will be removed from the tanks, solidified, and disposed at an appropriate disposal facility. The sludge from the tanks in this system will be removed and disposed at an appropriate disposal facility. After removal of tank contents, the interior of the tanks will be rinsed, and rinsate collected will be solidified and disposed at an appropriate disposal facility. The tanks will then be removed and disposed at an appropriate disposal facility. The excavated areas will be backfilled with NTS native fill, and all remaining open lines from tank connections will be grouted.

- CAS 12-04-02, Septic Tanks, contains no COCs above FALs. No further action is required for this site; however, as a BMP, the liquid contents will be removed from the tanks, solidified, and disposed at an appropriate disposal facility. If it is practical to remove the tanks, then sludge will be removed from the tanks and disposed at an appropriate disposal facility. The tanks will then be removed and disposed at an appropriate disposal facility. The excavated areas will be backfilled with NTS native fill, and all remaining open lines from tank connections will be grouted. If it is not practical to remove the tanks due to active utilities being present within close proximity to the tanks, then sludge will not be removed from the tanks, and the tanks will be filled with inert material and left in place.

- CAS 12-04-03, Septic Tank, contains no COCs above FALs. No further action is required for this site; however, as a BMP, the liquid contents will be removed from the tanks, solidified, and disposed at an appropriate disposal facility. If it is practical to remove the tanks, then sludge will be removed from the tanks and disposed at an appropriate disposal facility. The tanks will then be removed and disposed at an appropriate disposal facility. The excavated areas will be backfilled with NTS native fill, and all remaining open lines from tank connections will be grouted. If it is not practical to remove the tanks due to active utilities being present within close proximity to the tanks, then sludge will not be removed from the tanks, and the tanks will be filled with inert material and left in place.

- CAS 12-47-01, Wastewater Pond, contains no COCs above FALs. No further action is required for this site; however, as a BMP, this area will be recorded in the FIMS database as an administrative UR area. No postings or post-closure monitoring will be required.

- CAS 18-03-01, Sewage Lagoons, contains no COCs above FALs. No further action is required for this site; however, as a BMP, approximately 60 feet of 6-inch-diameter asbestos cement pipe will be removed and disposed at an appropriate disposal facility.

- CAS 18-99-09, Sewer Line (Exposed), contains no COCs above FALs. No further action is required for this site, and no work will be performed. 


\subsection{INTRODUCTION}

Corrective Action Unit (CAU) 151, Septic Systems and Discharge Area, is listed in the Federal Facility Agreement and Consent Order (FFACO) of 1996 (FFACO, 1996). CAU 151 consists of eight Corrective Action Sites (CASs) located in Areas 2, 12, and 18 of the Nevada Test Site (NTS), which is located approximately 65 miles northwest of Las Vegas, Nevada (Figure 1). CAU 151 consists of the following CASs:

- CAS 02-05-01, UE-2ce Pond

- CAS 12-03-01, Sewage Lagoons (6)

- CAS 12-04-01, Septic Tanks

- CAS 12-04-02, Septic Tanks

- CAS 12-04-03, Septic Tank

- CAS 12-47-01, Wastewater Pond

- CAS 18-03-01, Sewage Lagoon

- CAS 18-99-09, Sewer Line (Exposed)

Details of the site history and site characterization results for CAU 151 are provided in the approved Corrective Action Investigation Plan (CAIP) (U.S. Department of Energy, National Nuclear Security Administration Nevada Site Office [NNSA/NSO], 2004) and the approved Corrective Action Decision Document (CADD) (NNSA/NSO, 2006).

\subsection{Purpose}

The purpose of this Corrective Action Plan (CAP) is to provide the detailed scope of work required to implement the recommended corrective actions as specified in Section 4.0 of the approved CADD (NNSA/NSO, 2006).

\subsection{SCOPE}

The approved closure activities for CAU 151 include removal of septic tanks and their contents, removal of piping, and implementation of use restrictions (URs). Table 1 presents a summary of CAS-specific closure activities and contaminants of concern (COCs). Specific details of the corrective actions to be performed at each CAS are presented in Section 2.0 of this report.

\subsection{Corrective Action Plan Contents}

This CAP consists of the following sections and appendices:

- Section 1.0: Introduction

- Section 2.0: Detailed Statement of Work

- Section 3.0: Schedule

- Section 4.0: Post-Closure Plan

- Section 5.0: References 


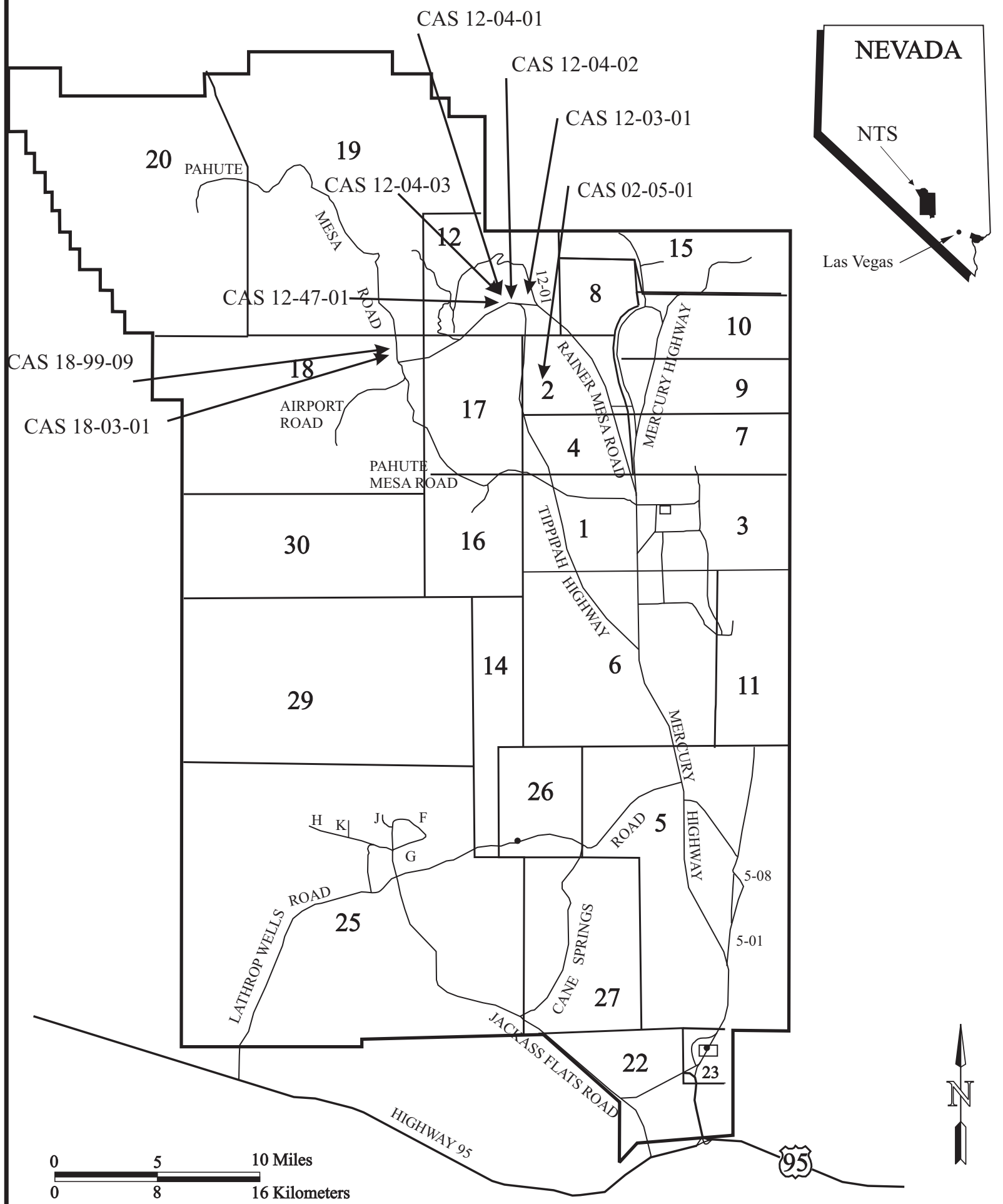

FIGURE 1

CORRECTIVE ACTION UNIT 151 Site LOCATION MAP 
Table 1. Corrective Action Unit 151 Closure Activities

\begin{tabular}{||c|c|c|c|l||}
\hline \hline CAS & Name & $\begin{array}{c}\text { Closure } \\
\text { Method }\end{array}$ & $\begin{array}{c}\text { Contaminants of } \\
\text { Concern }\end{array}$ & Scope of Work \\
\hline \hline 02-05-01 & UE-2ce Pond & $\begin{array}{c}\text { No Further } \\
\text { Action }\end{array}$ & None & None \\
\hline $12-03-01$ & Sewage Lagoons (6) & $\begin{array}{c}\text { Close in Place } \\
\text { (Lagoon A) and } \\
\text { No Further } \\
\text { Action (Lagoons } \\
\text { B through G) }\end{array}$ & Arsenic & $\begin{array}{l}\text { For Lagoon A, implement UR } \\
\text { For Lagoons B and E, implement administrative UR as a } \\
\text { BMP } \\
\text { For Lagoons C, D, F, and G, no activities }\end{array}$ \\
\hline $12-04-01$ & Septic Tanks & $\begin{array}{c}\text { Clean Closure } \\
\text { System \#1) and } \\
\text { No Further } \\
\text { Action } \\
\text { (System \#4) }\end{array}$ & $\begin{array}{c}\text { 1,4-Dichlorobenzene, } \\
\text { Trichloroethene, } \\
\text { Cesium-137, and } \\
\text { Aroclor-1254 }\end{array}$ & $\begin{array}{l}\text { - For System \#1, remove and solidify liquid from tanks, } \\
\text { remove sludge from tanks, rinse and excavate tanks, and } \\
\text { backfill excavations } \\
\text { For System \#4, as a BMP, remove liquid and sludge from } \\
\text { tanks, excavate tanks, backfill excavations, and grout } \\
\text { remaining lines }\end{array}$ \\
\hline $12-04-02$ & Septic Tanks & $\begin{array}{c}\text { No Further } \\
\text { Action }\end{array}$ & None & $\begin{array}{l}\text { As a BMP, remove liquid and sludge from tanks, excavate } \\
\text { tanks, backfill excavations, and grout remaining lines }\end{array}$ \\
\hline $12-04-03$ & Septic Tank & $\begin{array}{c}\text { No Further } \\
\text { Action }\end{array}$ & None & $\begin{array}{l}\text { As a BMP, remove liquid and sludge from tanks, excavate } \\
\text { tanks, backfill excavations, and grout remaining lines }\end{array}$ \\
\hline $12-47-01$ & Wastewater Pond & $\begin{array}{c}\text { No Further } \\
\text { Action }\end{array}$ & None & As a BMP, implement administrative UR \\
\hline $18-03-01$ & Sewage Lagoon & $\begin{array}{c}\text { No Further } \\
\text { Action }\end{array}$ & None & $\begin{array}{c}\text { As a BMP, remove approximately 60 feet of asbestos } \\
\text { cement pipe }\end{array}$ \\
\hline $18-99-09$ & Sewer Line (Exposed) & $\begin{array}{c}\text { No Further } \\
\text { Action }\end{array}$ & None & None \\
\hline \hline
\end{tabular}

BMP: best management practice

CAS: Corrective Action Site

UR: use restriction 
- Appendix A.1: Engineering Specifications and Drawings

- Appendix A.2: Sampling and Analysis Plan

- Appendix A.3: Project Organization

- Library Distribution List

Appendix A.1 is included in this CAP as required by the approved FFACO outline, but contains no material because engineering specification or drawings are not required for closure of CAU 151. Similarly, Appendix A.2 is included as required but contains no material because Section 2.4 provides sufficient details on sampling. 


\subsection{DETAILED STATEMENT OF WORK}

The approved corrective actions, as evaluated in Section 3.0 of the CADD and identified in Section 4.0 of the CADD (NNSA/NSO, 2006) for CAU 151, include:

- CAS 02-05-01, UE-2ce Pond: No Further Action

- CAS 12-03-01, Sewage Lagoons (6): Close in Place with Administrative Controls (Lagoon A) and No Further Action (Lagoons B through G)

- CAS 12-04-01, Septic Tanks: Clean Closure (System \#1) and No Further Action (System \#4)

- CAS 12-04-02, Septic Tanks: No Further Action

- CAS 12-04-03, Septic Tank: No Further Action

- CAS 12-47-01, Wastewater Pond: No Further Action

- CAS 18-03-01, Sewage Lagoon: No Further Action

- CAS 18-99-09, Sewer Line (Exposed): No Further Action

\subsection{CORRECTIVE ACTIONS}

The corrective action alternatives for CAU 151 are identified in Section 4.0 of the CADD (NNSA/NSO, 2006) and were approved by the Nevada Division of Environmental Protection (NDEP). The objective of the corrective actions is to prevent or mitigate adverse environmental impacts and migration of contamination. The corrective actions and best management practices (BMPs) for CAU 151 are identified below.

\subsubsection{Alternative 1, No Further Action}

\subsubsection{Corrective Action Site 02-05-01, UE-2ce Pond}

This site is located in Area 2 and consists of an excavated pond, surrounding bermed area, and surface trench running between the pond and the UE-2ce water well. A gravel outwash mound is located in the center of the pond. In addition to the mound, miscellaneous debris including cables, scrap metal, and wood is scattered on the bottom and around the pond. No COCs are present above Final Action Levels (FALs). No further action is required for this CAS, and no work will be performed.

\subsubsection{Corrective Action Site 12-03-01, Sewage Lagoons (6)}

This site is located in the northeast portion of the Area 12 camp and consists of Lagoons A through G (Figure 2). These lagoons were constructed in the late 1960s and early 1980s. Lagoons A through D and F received effluent from the septic systems and buildings in the Area 12 camp until the closing of the septic tanks in the early 1980s. The septic tanks were then bypassed, and all effluent was discharged into to Lagoon $\mathrm{E}$ and overflowed to Lagoon $\mathrm{G}$. In the early 1990s, these lagoons were abandoned, and two sewage lagoons were constructed east of Area 12. Figure 3 shows the relative location of CAS 12-03-01 to the other CASs in Area 12.

No COCs are present above FALs at Lagoons C, D, F, and G. No further action is required for these lagoons, and no work will be performed. 


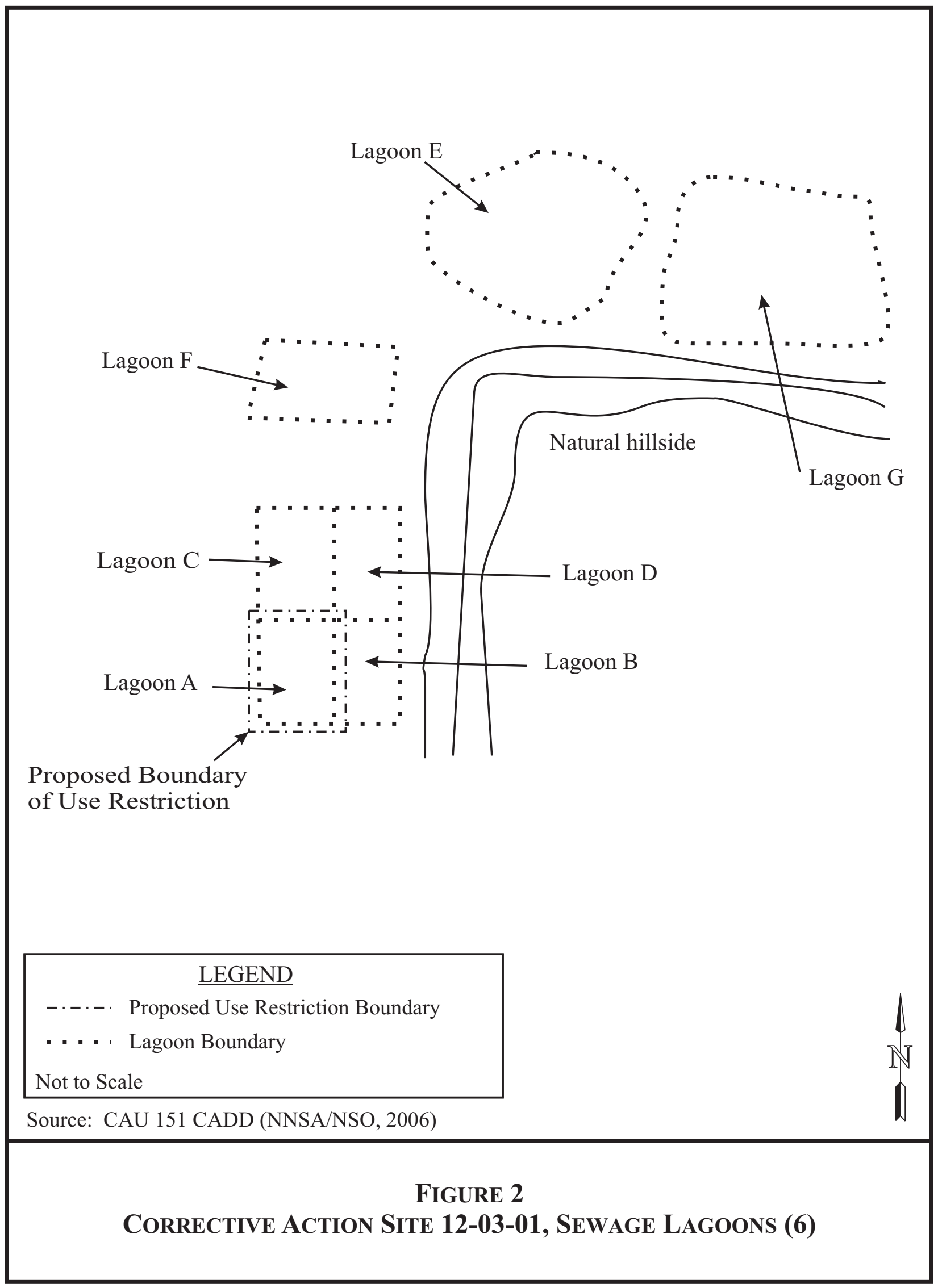




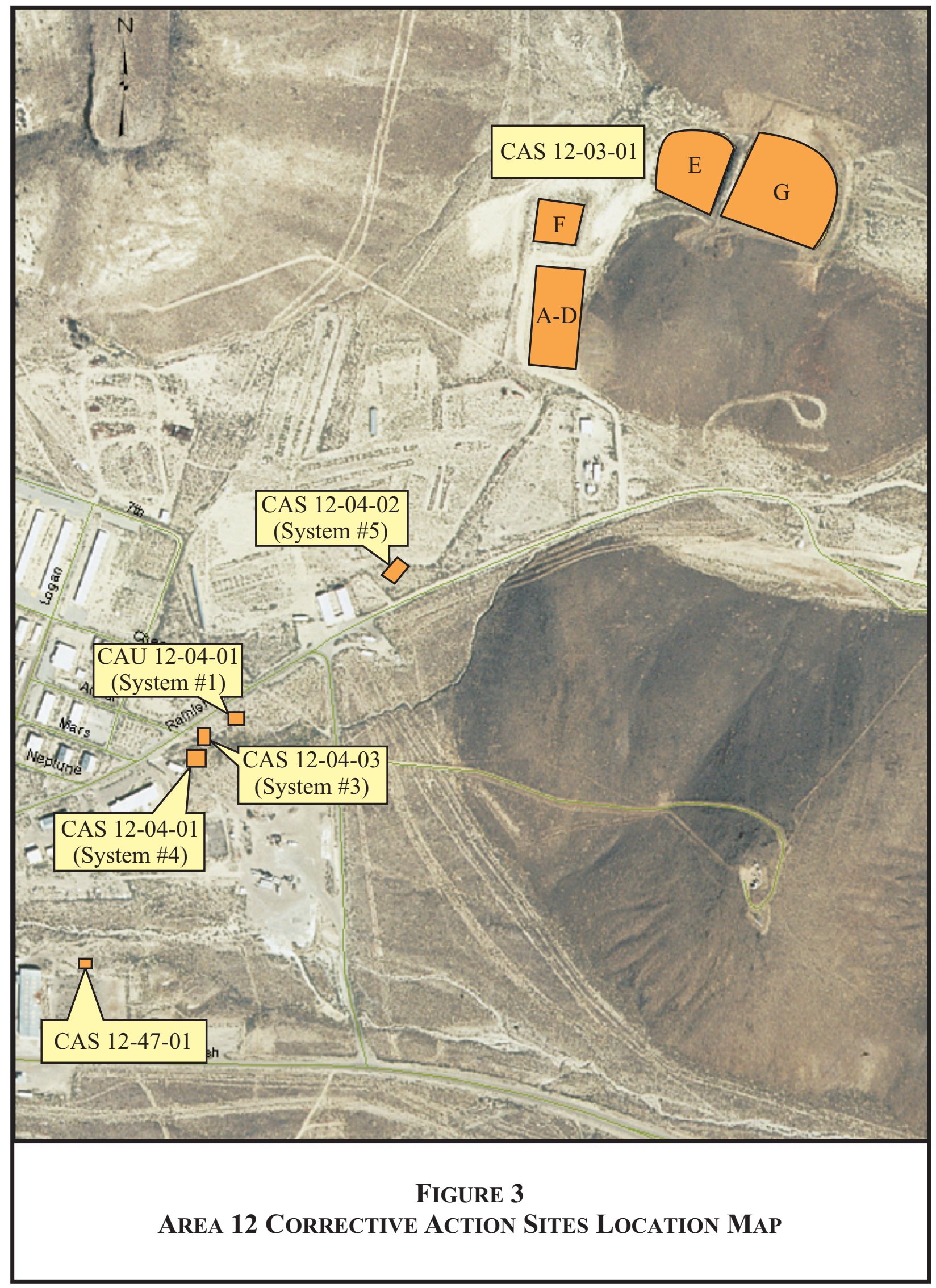


In addition, no COCs are present above FALs at Lagoons B and E. Arsenic was present at Lagoon B above the preliminary action level (PAL), which was defined as the U.S. Environmental Protection Agency (EPA) Region 9 preliminary remediation goal (PRG) for industrial soil; however, it did not exceed the FAL that was calculated based on an occasional use scenario. Semi-volatile organic compounds (SVOCs) were present at Lagoon E above the PAL, which was defined as the EPA Region 9 PRG for industrial soil; however, it did not exceed the FAL that was calculated based on an occasional use scenario. No further action is required for these lagoons; however, as a BMP, these areas will be recorded in the Facilities Information Management System (FIMS) database as administrative UR areas to protect future workers from an exposure should the land use scenario change from that used to calculate the FALs. No postings or post-closure monitoring will be required. No verification samples will be collected at Lagoons B through G since no COCs were identified during site characterization.

Lagoon A, which will be closed in place with administrative controls, is discussed in Section 2.1.3 of this document.

\subsubsection{Corrective Action Site 12-04-01, Septic Tanks (System \#4)}

This site is located in the northeast portion of Area 12 and consists of two septic tanks referred to as System \#1 and four septic tanks referred to as System \#4. These systems are associated with and discharge into CAS 12-03-01, Sewage Lagoons (6). System \#1 consists of two septic tanks, two manholes, four access covers, and the associated 6-inch (in.) vitrified clay pipe (VCP). System \#4 consists of four septic tanks, eight access covers, and the associated 6-in. VCP.

No COCs are present above FALs in the tanks associated with System \#4. Figure 4 provides approximate liquid and sludge volumes in the septic tanks associated with System \#4. No further action is required for System \#4; however, as a BMP, the liquid contents will be removed from the four tanks in this system, solidified, and disposed at an appropriate disposal facility. If it is practical to remove the tanks, then sludge will be removed from the tanks and disposed at an appropriate disposal facility. The tanks will then be removed and disposed at an appropriate disposal facility. The excavated areas will be backfilled with NTS native fill, and all remaining open lines from tank connections will be grouted. If it is not practical to remove the tanks due to their close proximity to active utilities, then sludge will not be removed from the tanks, and the tanks will be filled with inert material and left in place. No verification samples will be collected since no COCs were identified during site characterization.

System \#1, which will be clean closed, is discussed in Section 2.1.2 of this document.

\subsubsection{Corrective Action Site 12-04-02, Septic Tanks}

This site is located in the northeast portion of Area 12 and consists of six septic tanks referred to as System \#5. These septic tanks are associated with and discharge into CAS 12-03-01, Sewage Lagoons (6). This system was constructed between 1961 and 1962 and consists of six septic tanks, two manholes, eight access covers, and the associated VCP.

No COCs are present above FALs in the septic tanks at this site. Figure 5 provides approximate liquid and sludge volumes for these septic tanks. No further action is required for this CAS; however, as a BMP, the liquid contents will be removed from the septic tanks, solidified, and disposed at an appropriate disposal facility. If it is practical to remove the tanks, then sludge will be removed from the tanks and disposed at an appropriate disposal facility. The tanks will then 


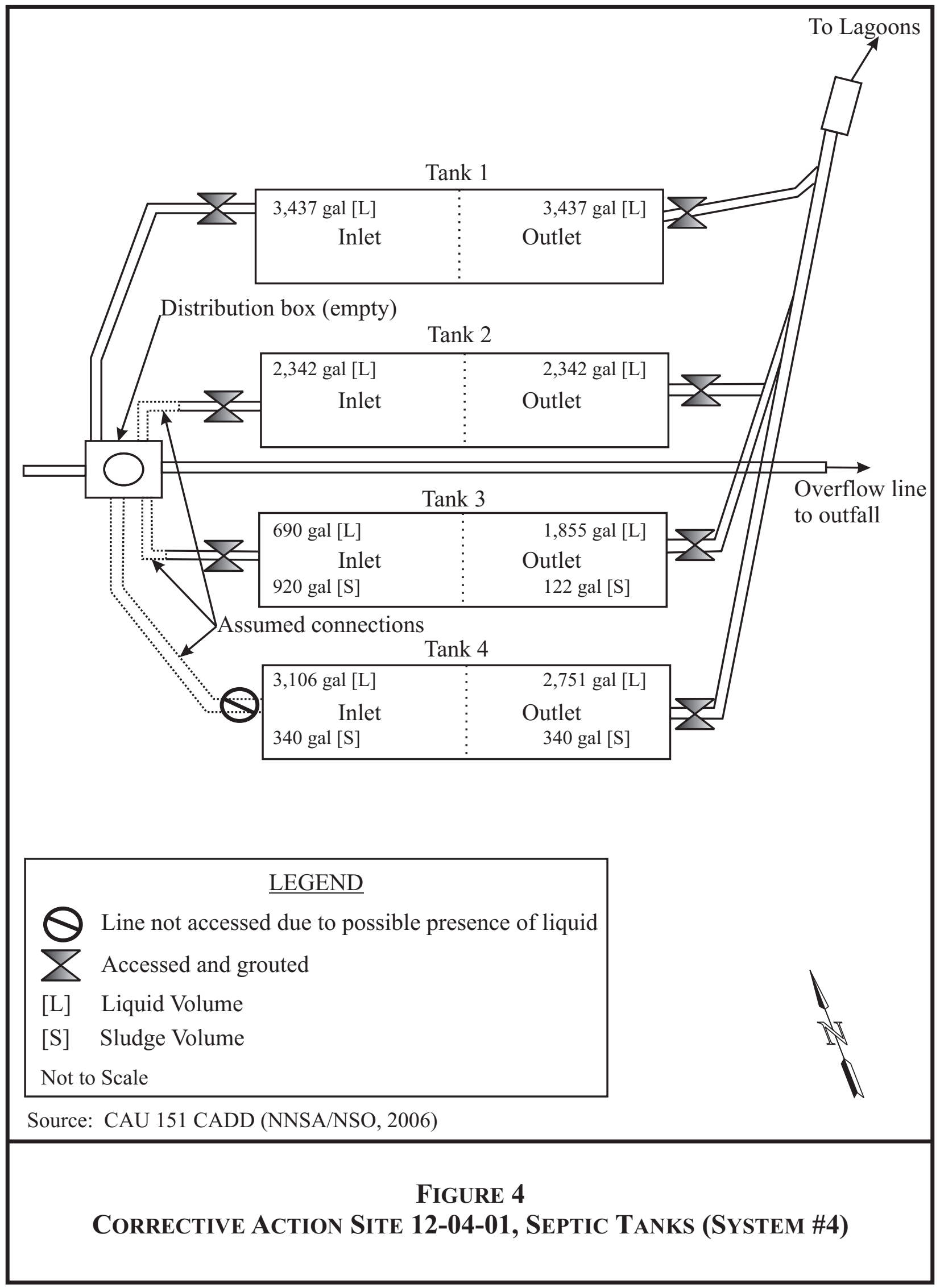




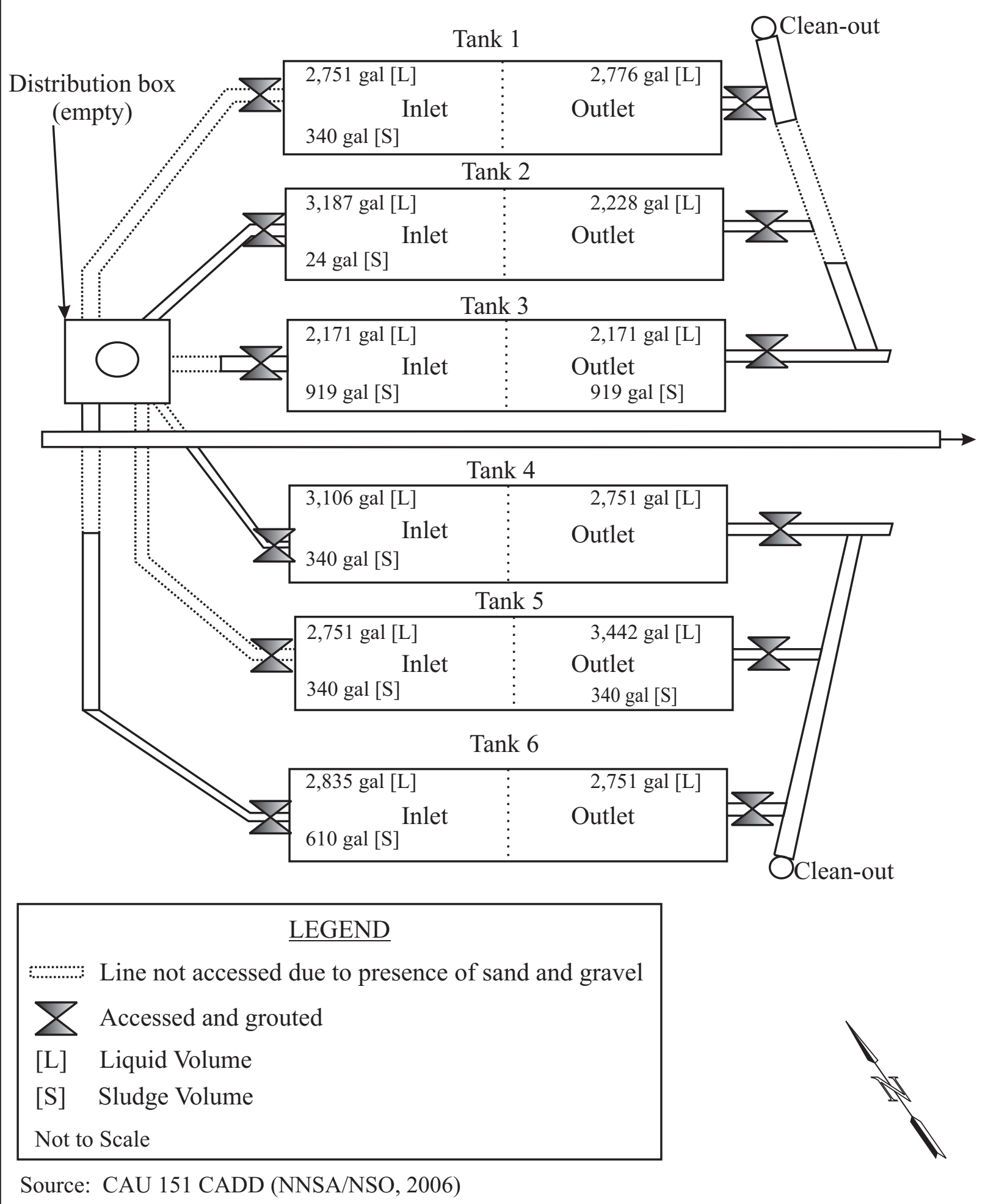

FIGURE 5

CORRECTIVE ACTION Site 12-04-02, SePtic TANKS (System \#5) 
be removed and disposed at an appropriate disposal facility. The excavated areas will be backfilled with NTS native fill, all remaining open lines from tank connections will be grouted. If it is not practical to remove the tanks due to their close proximity to active utilities, then sludge will not be removed from tanks, and the tanks will be filled with inert material and left in place. No verification samples will be collected since no COCs were identified during site characterization.

\subsubsection{Corrective Action Site 12-04-03, Septic Tank}

This site is located in the east-central and northeast portions of Area 12 and consists of four septic tanks referred to as System \#3. These septic tanks are associated with and discharge into CAS 12-03-01, Sewage Lagoons (6). This system consists of four septic tanks, two manholes, one access cover, and the associated VCP.

No COCs are present above FALs in the septic tanks at this site. Figure 6 provides approximate liquid and sludge volumes for these septic tanks. No further action is required for this CAS; however, as a BMP, the liquid contents will be removed from the septic tanks, solidified, and disposed at an appropriate disposal facility. If it is practical to remove the tanks, then sludge will be removed from the tanks and disposed at an appropriate disposal facility. The tanks will then be removed and disposed at an appropriate disposal facility. The excavated areas will be backfilled with NTS native fill, all remaining open lines from tank connections will be grouted. If it is not practical to remove the tanks due to their close proximity to active utilities, then sludge will not be removed from tanks, and the tanks will be filled with inert material and left in place. No verification samples will be collected since no COCs were identified during site characterization.

\subsubsection{Corrective Action Site 12-47-01, Wastewater Pond}

This site is located in the south-central portion of the Area 12 camp and consists of two sumps (evaporation ponds) and the associated piping (Figure 7). No COCs are present above FALs. SVOCs, total petroleum hydrocarbons (TPH)-diesel range organics, and polychlorinated biphenyls (PCBs) (aroclor-1254) were present in the soil above PALs, which were defined as the EPA Region 9 PRGs for industrial soil. TPH and PCBs did not exceed the FALs that were calculated based on an occasional use scenario. SVOCs were attributed to asphalt. No further action is required for this site; however, as a BMP, this area will be recorded in the FIMS database as an administrative UR area to protect future workers from an exposure should the land use scenario change from that used to calculate the FALs. No postings or post-closure monitoring will be required. No verification samples will be collected since no COCs were identified during site characterization.

\subsubsection{Corrective Action Site 18-03-01, Sewage Lagoon}

This site is located in Area 18 at the Area 17 camp and consists of two sewage lagoons and the associated collection piping (Figure 8). These lagoons were constructed in the early 1960s and were active until the 1980s. They were used to collect sanitary effluent from the Area 17 camp administrative offices and the sanitary and possibly industrial effluent from the construction support area to the east of the lagoons. No COCs are present above FALs. No further action is required for this site; however, as a BMP, approximately 60 feet of 6-in.-diameter asbestos cement pipe will be removed from beneath the inlet walkway and disposed at an appropriate 
Tank 4

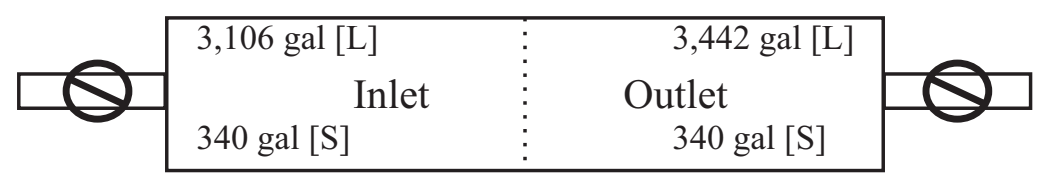

Tank 3

\begin{tabular}{|c|c|}
\hline $3,659 \mathrm{gal}[\mathrm{L}]$ & $3,659 \mathrm{gal}[\mathrm{L}]$ \\
\hline $122 \mathrm{gal}[\mathrm{S}]{ }^{\text {Inlet }}$ & $\begin{array}{l}\text { Outlet } \\
122 \mathrm{gal}[\mathrm{S}]\end{array}$ \\
\hline
\end{tabular}

\section{Tank 2}

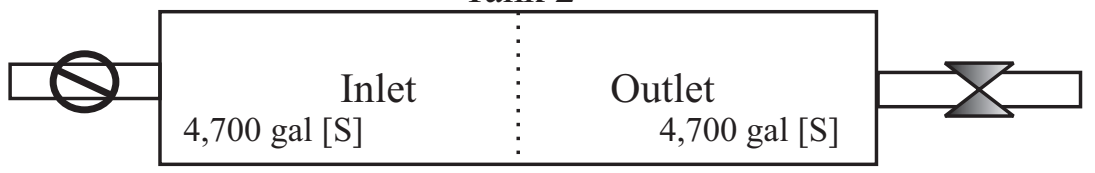

Tank 1

$\boldsymbol{P a n} \begin{array}{ccc}1,835 \mathrm{gal}[\mathrm{L}] & \vdots & 2,171 \mathrm{gal}[\mathrm{L}] \\ \text { Inlet } & \vdots & \text { Outlet } \\ 1,255 \mathrm{gal}[\mathrm{S}] & \vdots & 919 \mathrm{gal}[\mathrm{S}]\end{array}$

\section{LEGEND}

$\bigotimes$ Line not accessed due to possible presence of liquid

$\sum$ Accessed and grouted

[L] Liquid Volume

[S] Sludge Volume

Not to Scale

Source: CAU 151 CADD (NNSA/NSO, 2006)

FIGURE 6

Corrective ACtion Site 12-04-03, SePtic TANK (System \#3) 


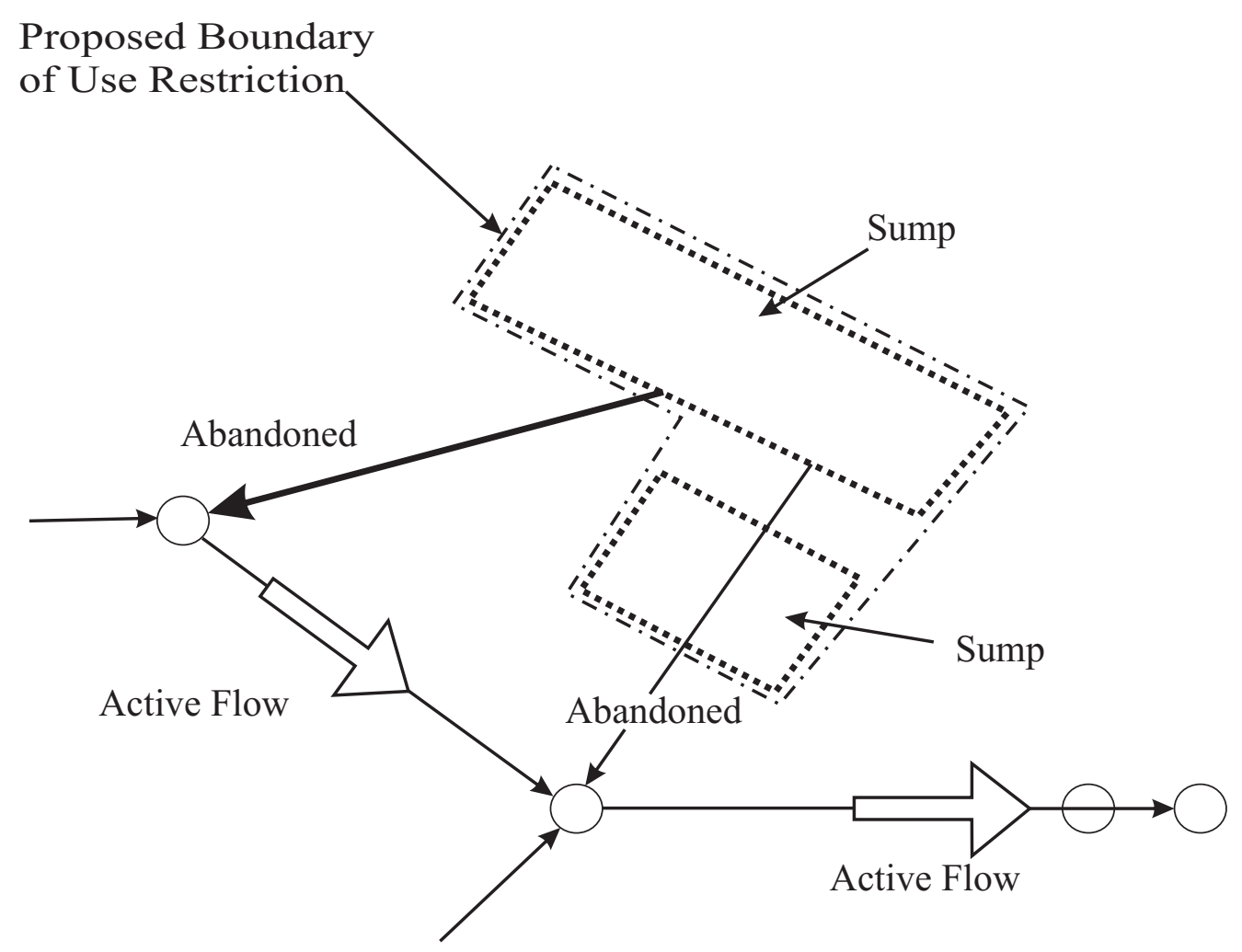

\section{LEGEND}

-. - - Proposed Use Restriction Boundary

........ Sump

O Manhole

Not to Scale

Source: CAU 151 CADD (NNSA/NSO, 2006)

FIGURE 7

Corrective Action Site 12-47-01, Wastewater Pond 


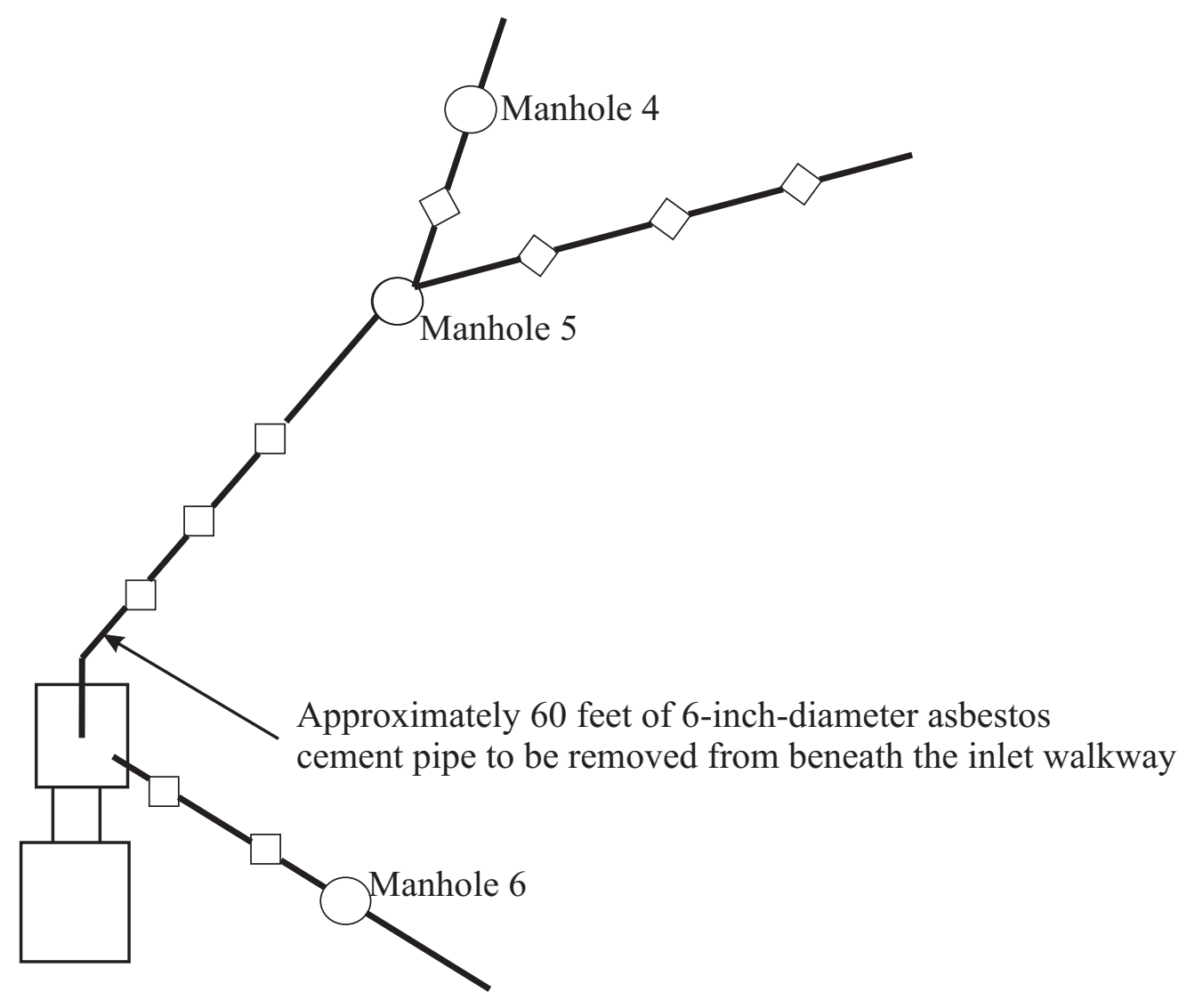

\section{LEGEND}

$\square$ Lagoon

$\triangle$ Trench

Manhole

Not to Scale

Source: CAU 151 CADD (NNSA/NSO, 2006)

FIGURE 8

Corrective ACtion Site 18-03-01, SEWAGE LAGoON 
disposal facility. No verification samples will be collected since no COCs were identified during site characterization.

\subsubsection{Corrective Action Site 18-99-09, Sewer Line (Exposed)}

This site is located in Area 18 at the Area 17 camp and consists of a 6-in. diameter VCP. No COCs are present above FALs. No further action is required for this CAS, and no work will be performed.

\subsubsection{Alternative 2, Clean Closure}

\subsubsection{Corrective Action Site 12-04-01, Septic Tanks (System \#1)}

This site is located in the east-central and northeast portions of Area 12 and consists of two septic tanks referred to as System \#1 and four septic tanks referred to as System \#4. These systems are associated with and discharge into CAS 12-03-01, Sewage Lagoons (6). System \#1 consists of two septic tanks, two manholes, four access covers, and the associated 6-in. VCP.

Results of the characterization reported toxicity characteristic leaching procedure (TCLP) volatile organic compounds (VOCs), Cesium-137, and PCBs above FALs in the tanks associated with System \#1. The COCs for this system are summarized in Table 2.

\section{TABle 2. CoRrective ACTION Site 12-04-01 (System \#1) Characterization SumMARY}

\begin{tabular}{|l|l|l|l||}
\hline \multicolumn{1}{|c|}{ COC } & \multicolumn{1}{c|}{ Location } & \multicolumn{1}{c|}{ Concentration } & \multicolumn{1}{c|}{ FAL } \\
\hline \hline TCLP 1,4-Dichlorobenzene & Tank 5 inlet & 17 milligrams per liter & 7.5 milligrams per liter \\
\hline TCLP Trichloroethene & Tank 5 inlet & 36 milligrams per liter & 0.5 milligrams per liter \\
\hline Cesium-137 & Tank 5 outlet & 13.6 picoCuries per gram & 12.2 picoCuries per gram \\
\hline Aroclor-1254 (PCBs) & Tank 5 outlet & 37,000 micrograms per kilogram & 27,700 micrograms per kilogram \\
\hline TCLP 1,4-Dichlorobenzene & Tank 6 inlet & 7.8 milligrams per liter & 7.5 milligrams per liter \\
\hline
\end{tabular}

COC: contaminant of concern

FAL: final action level

PCBs: polychlorinated biphenyls

TCLP: toxicity characteristic leaching procedure

System \#1 will be clean closed. Figure 9 provides approximate liquid and sludge volumes for these septic tanks. The liquid contents will be removed from the two tanks in this system, solidified, and disposed at an appropriate disposal facility. The sludge from these two tanks will be removed, sampled for waste characterization purposes, and disposed at an appropriate disposal facility. The interiors of the tanks will be rinsed, and the rinsate collected will be solidified and disposed with the sludge from the tanks. The tanks will then be removed and disposed at an appropriate disposal facility.

A minimum of five soil verification samples will be collected from the excavation, at least one from each side wall and one from the base of the excavation. Samples will be analyzed for TCLP VOCs, PCBs, gamma-emitting radionuclides, and any additional COCs identified during waste characterization to verify that COCs have not been released to the surrounding soil. The excavation will be backfilled with NTS native fill, and all remaining open lines from tank connections will be grouted. 
Tank 5

$8 \begin{array}{ccc}645 \mathrm{gal}[\mathrm{L}] & \vdots & 488 \mathrm{gal}[\mathrm{L}] \\ \text { Inlet } & \vdots & \text { Outlet } \\ 610 \mathrm{gal}[\mathrm{S}] & \vdots & 122 \mathrm{gal}[\mathrm{S}]\end{array}$

\section{Tank 6}

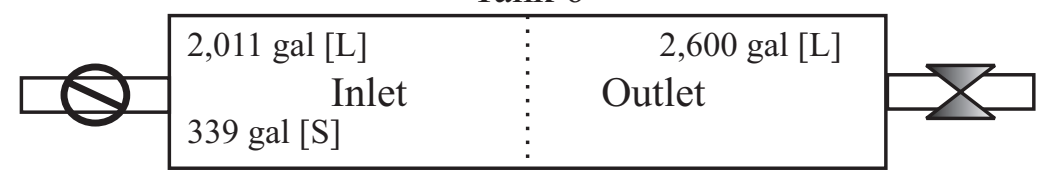

\section{LEGEND}

$\bigotimes$ Line not accessed due to possible presence of liquid

$\searrow$ Accessed and grouted

[L] Liquid Volume

[S] Sludge Volume

Not to Scale

Source: CAU 151 CADD (NNSA/NSO, 2006)

FIGURE 9

CORRECTIVE ACTION Site 12-04-01, SePtic TANKS (System \#1) 


\subsubsection{Alternative 3, Close in Place with Administrative Controls}

\subsubsection{Corrective Action Site 12-03-01, Sewage Lagoons (6) (Lagoon A)}

This site is located in the northeast portion of the Area 12 camp and consists of Lagoons A through G (Figure 2). These lagoons were constructed in the late 1960s and early 1980s. Lagoons A through D and F received effluent from the septic systems and buildings in the Area 12 camp until the closing of the septic tanks in the early 1980s. The septic tanks were then bypassed, and all effluent was discharged into to Lagoon $\mathrm{E}$ and overflowed to Lagoon $\mathrm{G}$. In the early 1990s, these lagoons were abandoned, and two sewage lagoons were constructed east of Area 12.

At Lagoon A, arsenic is present at concentrations greater than the FAL. The vertical extent of contamination appears to be limited to the upper 5 feet of soil, and concentrations decrease with depth. This lagoon will be closed in place with administrative controls, and a UR will be implemented. No verification samples will be collected.

\subsection{Construction Quality Assurance/Quality ConTrol}

Construction activities are limited to removal of liquid and sludge from tanks, removal of tanks, backfilling, and posting of UR warning signs. No engineered structures will be constructed as part of site closure. Therefore, a construction quality assurance/quality control (QA/QC) plan is not required.

\subsubsection{Construction Field Sample Collection Activities}

Construction field samples are not necessary for the closure of CAU 151. Samples will be collected for the purpose of waste stream characterization and to verify that the approved cleanup criteria have been met. Sample collection activities are addressed in Section 2.4 of this document.

\subsubsection{Construction Laboratory/Analytical Data Quality Indicators}

CAU 151 closure activities are limited to removal of liquid and sludge from tanks, removal of tanks, backfilling, and posting of UR warning signs. Therefore, a construction QA/QC plan is not required, and construction Data Quality Indicators (DQIs) are not applicable. To ensure that backfill material remains consistent, all fill will be taken from an approved borrow source.

\subsection{WASTE MANAGEMENT}

All waste streams will be managed and disposed according to applicable federal and state regulations, U.S. Department of Energy (DOE) Orders, U.S. Department of Transportation regulations, and company waste management procedures. CAU 151 closure activities may generate sanitary waste/construction debris, low-level waste (LLW), hazardous waste (HW), mixed waste (MW), and/or Toxic Substances Control Act (TSCA)-regulated waste. Waste generated during closure activities will be properly managed and shipped to an onsite or offsite 
disposal facility. Confirmation of waste disposal or transfer to National Security Technologies, LLC (NSTec), Waste Generator Services (WGS) for management and disposal will be included in the CAU 151 Closure Report (CR).

\subsubsection{Waste Minimization}

All work activities that generate waste will strive to minimize the volume of waste generated. Special care will be taken to properly characterize and segregate waste streams to avoid the generation of additional waste.

\subsubsection{Waste Types}

\subsubsection{Sanitary Waste and Construction Debris}

Sanitary waste (e.g., non-impacted personal protective equipment [PPE] and general trash) and construction debris (e.g., wood, concrete block, metal, plastic) removed from sites will be radiologically screened for free release (U.S. Department of Energy, Nevada Operations Office, 2004) and disposed as sanitary waste in an onsite permitted landfill.

\subsubsection{Low-Level Waste}

Closure activities may potentially generate LLW at CAS 12-04-01, Septic Tanks (System \#1). The waste will be characterized by process knowledge, laboratory analysis of samples, and/or radiological screening results, and a profile for disposal will be prepared. All LLW will be managed and disposed according to Organization Procedure (OP) OP-2151.304, "Radioactive Waste Tracking, Handling, and Management at the Nevada Test Site” (NSTec, 2006b), and all applicable federal and state regulations. All LLW will be packaged in the presence of a Waste Certification Official and WGS personnel according to OP-2151.304 (NSTec, 2006b). LLW will be stored in a radioactive materials area until transport to an appropriate disposal facility can be arranged.

\subsubsection{Hazardous Waste}

HW may be generated during closure activities at CAS 12-04-01, Septic Tanks (System \#1). The waste will be characterized by process knowledge and/or laboratory analysis of samples, and a waste profile for disposal will be prepared. All HW will be managed and disposed according Company Directive (CD) CD-0442.006, “Hazardous Waste Management” (Bechtel Nevada [BN], 2006), and all applicable federal and state regulations. Upon generation, HW will be containerized and stored in a satellite accumulation area or a 90-Day Hazardous Waste Accumulation Area, depending on the amount of waste generated. After an approved waste profile is generated, the waste will be disposed at a permitted treatment, storage, and disposal facility.

\subsubsection{Mixed Waste}

MW may be generated during closure activities at CAS 12-04-01, Septic Tanks (System \#1). MW will be managed and disposed according to all applicable NSTec, state, and federal procedures and regulations. 


\subsubsection{Toxic Substances Control Act-Regulated Waste}

TSCA-regulated waste may be generated during closure activities at CAS 12-04-01, Septic Tanks (System \#1). The waste will be characterized by process knowledge and/or laboratory analysis of samples, and a waste profile for disposal will be prepared. All TSCA-regulated waste will be managed and disposed according to CD-0442.010, “Waste Management” (BN, 2005a), and all applicable federal and state regulations. Upon generation, waste will be containerized and stored according to CD-0442.010 (BN, 2005a). After an approved waste profile is generated, the waste will be disposed at a permitted treatment, storage, and disposal facility.

\subsubsection{Decontamination Waste}

All radiologically-impacted equipment will be surveyed prior to release from an exclusion zone. Any equipment that becomes contaminated during closure activities will be decontaminated onsite. Dry decontamination will be the preferred method. For larger pieces of equipment that cannot be effectively decontaminated using dry decontamination techniques, wet decontamination techniques will be used. All decontamination rinsate will be managed appropriately according to applicable regulations, and once characterized, properly disposed.

\subsubsection{Personal Protective Equipment}

All PPE that becomes contaminated during closure activities will be disposed with the appropriate waste stream.

\subsection{CONFIRMATION OF CORRECTIVE ACTIONS}

Accurate and defensible analytical data will be collected to characterize waste and verify that the closure objectives are met. In addition, visual inspection and photographic documentation will verify final site conditions.

\subsubsection{No Further Action}

At eight CASs, no COCs are present above FALs and require no further action; however, BMPs will be implemented at six of these CASs. With the exception of CAS 12-03-01 (Lagoon A) and CAS 12-04-01 (System \#1), the final site conditions will be verified by visual inspection and photographic documentation included in the CR.

\subsubsection{Clean Closure}

CAS 12-04-01, Septic Tanks (System \#1), will be considered clean closed after laboratory results verify that verification samples are below the applicable action levels. In addition, removal of materials will be confirmed by visual inspection and photographic documentation of final site conditions.

\subsubsection{Close in Place with Administrative Controls}

For CAS 12-03-01, Sewage Lagoons (6) (Lagoon A), the final site conditions will be verified by visual inspection and photographic documentation included in the CR. 


\subsubsection{Sample Collection Methods}

All soil verification samples will be collected by qualified NSTec Environmental Restoration personnel. If it is required, waste characterization samples will be collected by qualified WGS personnel. Samples will be collected by hand, using disposable pre-cleaned or decontaminated sampling equipment according to Organization Instruction (OI) OI-2152.108, "Soil Sampling” (BN, 2000b). Liquid samples will be collected using a dipper or other transfer devices according to OI-2154.120, "Soil, Waste, and Water Sampling for Characterization and Compliance" (BN, 2005b). All samples will be labeled with a unique sample identification number using the CAS number followed by the sample number (e.g., 120401-V1). Additionally, waste characterization samples will be labeled using the CAS number followed by the sample number (e.g., 120401-WC1).

All samples will be collected in clean containers, labeled appropriately, sealed with a tamper-proof seal, bagged, placed on ice in a cooler, and transported to the NSTec Environmental Technical Services group under an "Analytical Laboratory Service Request and Chain of Custody Report” form (NSTec, 2006a). Sample collection date, time, and other pertinent information will be logged on this form, which establishes and maintains sample traceability, and recorded in a bound project field notebook according to OI-2152.100, "Sample Chain of Custody” (BN, 2000a).

The Environmental Technical Services group is responsible for sample management and shipment of the samples to an approved offsite laboratory for analysis. Samples will be analyzed by EPA-approved analytical methods at EPA-approved laboratories (EPA, 1996). Sample analysis will include laboratory analysis of QA/QC samples and will follow stringent QA/QC procedures (EPA, 1996). Sample analysis for radionuclides will be performed according to the Environmental Measurements Laboratory Procedures Manual (DOE, 1997).

One set of QA/QC samples will be collected for every twenty environmental samples or one per sample batch. QA/QC samples will include blind duplicates, matrix spike/matrix spike duplicates, and equipment rinsate samples. All blind duplicates will be labeled with a unique sample number.

\subsubsection{Laboratory/Analytical Data Quality Indicators}

Data Quality Objectives (DQOs) are qualitative and quantitative statements that specify the quality of the data required supporting closure of a site. The DQOs for CAU 151 were defined in Appendix A.1 of the CAIP (NNSA/NSO, 2004) using the Seven Step DQO Process developed by the EPA (EPA, 2006b). Three conceptual site models were developed, and these models were reconciled with the results of the site investigation in the CADD (NNSA/NSO, 2006).

CAS 12-04-01, Septic Tanks (System \#1), will be clean closed and will require the collection and analysis of verification samples. If it is required, waste characterization samples will be collected for disposal purposes. All laboratory data generated during closure activities will be reviewed by project personnel to ensure the data are usable and complete according to the CAU 151 DQOs. In addition, as specified in the Industrial Sites Quality Assurance Project Plan (U.S. Department of Energy, National Nuclear Security Administration Nevada Operations Office [NNSA/NV], 2002), 100 percent of the data packages will be evaluated at the Tier I and Tier II levels using applicable OIs. These include OI-2151.303, "Validation of Radiological and Chemical Laboratory Data” (BN, 2004), and OI-2154.459, “Inorganic Data Verification and 
Validation” (BN, 2005c). OI-2154.459 is based on EPA functional guidelines (EPA, 2006a). Any data determined not to be valid will be identified in the CR.

DQIs are qualitative and quantitative statements that specify the data requirements of a project. The DQIs include precision, accuracy, representativeness, comparability, completeness, and sensitivity. These DQIs are discussed below.

\subsubsection{Precision}

Precision is a measure of agreement among a replicate set of measurements of the same property under similar conditions. This agreement is expressed as the relative percentage difference (RPD) between duplicate measurements (EPA, 1996). Precision applies to parameters sampled and analyzed in duplicate.

One duplicate sample will be collected per set of twenty or fewer verification samples. All duplicate samples will be collected from the same medium and analyzed for the same set of analytes. The precision of the analytical results will be assessed by calculating the RPD for a verification sample and its duplicate sample results. An RPD of less than or equal to 30 percent indicates acceptable precision (NNSA/NV, 2002).

\subsubsection{Accuracy}

Accuracy is a measure of the closeness of an individual measurement or the average of a number of measurements to the true value. Accuracy includes a combination of random error (precision) and systematic error (bias) components that result from sampling and analytical operations. This closeness is expressed as percent recovery (\%R) (EPA, 1996). Accuracy will be assessed by examining the \%R of laboratory control and spiked samples. A \%R within the range of 70 to 130 percent indicates satisfactory analytical accuracy (NNSA/NV, 2002).

\subsubsection{Representativeness}

Representativeness is a qualitative evaluation of measurement system performance. It is the degree to which sample data accurately and precisely represent a characteristic of a population, parameter variations at a sampling point, or an environmental condition (EPA, 1996).

Representativeness will be attained by ensuring that the sample locations, analytical parameters, analytical methods, sampling protocols, and sample handling all meet the project-specific objectives.

\subsubsection{Comparability}

Comparability is a qualitative measure that expresses the confidence that one data set can be compared to another. It will be achieved by using standardized field sampling procedures. The same analytical laboratory will perform the same analyses for all samples. Sample results will be reported in standard units to allow for comparison of the data.

\subsubsection{Completeness}

Completeness is a quantitative measure of data quality expressed as the percentage of valid data

obtained that satisfies the project-specific requirements. Since a limited number of samples will 
be collected for both waste characterization and verification of closure, 100 percent of the data collected needs to be of acceptable quality to maintain acceptable QA/QC standards.

\subsubsection{Sensitivity}

Sensitivity is the capability of a method or instrument to discriminate between measurement responses representing different levels of a variable of interest. This indicator is determined from the value of the standard deviation at the concentration level of interest. It represents the minimum difference of concentration that can be distinguished between two samples with a high degree of confidence. Sensitivity must be sufficient to detect contaminants at or below decision levels. Sensitivity will be achieved by analyzing all samples using appropriate EPA-approved analytical laboratories, methods, and instruments.

\subsection{Permits}

Prior to beginning field closure activities, planning documents and permits will be prepared. These documents will include a National Environmental Policy Act (NEPA) Checklist, a Real Estate/Operations Permit (REOP), Radiological Work Permits (RWPs), excavation permits, and blind penetration permits.

\subsubsection{National Environmental Policy Act Checklist}

A NEPA Checklist will be completed prior to all closure activities at the site. Closure activities will follow all applicable federal, state, and local laws, regulations, and permits regarding protection of the environment.

\subsubsection{Real Estate/Operations Permit}

A REOP will be obtained prior to beginning closure activities. The permit will establish NNSA/NSO as the prime authority possessing control of the site.

\subsubsection{Radiological Work Permit}

RWP(s) will be required for work at any radiologically-impacted site when radiological conditions require, as determined by NSTec Health Physics. RWPs will inform workers of the specific PPE necessary to protect them while performing their tasks and identify site-specific controls. The workers will be required to sign the RWP(s) and acknowledge their understanding of the requirements before entry into any radiologically controlled area, if present. The RWPs will be maintained by the Radiological Control Technician at the entrance to the radiologically controlled area. All site workers will be required to be Radiation Worker II-trained to perform work within a radiologically controlled area.

\subsubsection{Utility Clearances, Excavation Permits, and Blind Penetration Permits}

An excavation permit and a blind penetration permit will be obtained prior to beginning excavation activities. These permits require that a utility clearance be performed. A copy of the permit will be filed onsite throughout the duration of the project. 


\subsection{SCHEDULE}

All preparation and field activities are scheduled for completion in Fiscal Year 2008. The FFACO deadline for the CR is April 30, 2008. Sufficient flexibility will be incorporated into the field schedule to allow for minor difficulties (e.g., weather, equipment failure). NNSA/NSO shall notify NDEP of any condition or event that may impact the project schedule. 
CAP - CAU 151

Section: Schedule

Revision: 0

Date: March 2007

THIS PAGE INTENTIONALLY LEFT BLANK 


\subsection{POST-CLOSURE PLAN}

For CAU 151, the approved corrective action is Alternative 1, No Further Action, for CAS 02-05-01, CAS 12-03-01 (Lagoons B through G), CAS 12-04-01 (System \#4), CAS 12-04-02, CAS 12-04-03, CAS 12-47-01, CAS 18-03-01, and CAS 18-99-09. At CAS 12-03-01 (Lagoons B and E) and CAS 12-47-01, administrative URs will be implemented as a BMP; however, administrative URs do not require post-closure inspections. For CAS 12-04-01 (System \#1), the approved corrective action is Alternative 2, Clean Closure. For CAS 12-03-01 (Lagoon A), the approved corrective action is Alternative 3, Close in Place with Administrative Controls, and will include implementing a UR. Post-closure inspections of CAS 12-03-01 (Lagoon A) will be required to verify the postings and UR is maintained.

\subsection{INSPECTIONS}

Annual site inspections will be completed at CAS 12-03-01 (Lagoon A) for five years. After the fifth year, inspections will be conducted every five years for twenty years. Inspections consist of visual inspections of the postings to verify they are in place and readable and that the UR has been maintained. Any identified maintenance or repair requirements will be reported to NDEP and scheduled within ninety working days of discovery. The inspection report will be incorporated into the combined annual letter report and submitted to the NDEP. The letter report will include a discussion of observations and provide a record of repair or maintenance activities.

\subsection{MONITORING}

As no post-closure sampling or data collection will be performed, no post-closure monitoring is required at any CAS in CAU 151. However, post-closure inspections will be performed as identified above in Section 4.1.

\subsection{MAINTENANCE AND REPAIR}

If any maintenance and repair requirements are identified during site inspections, funding will be requested and the repairs scheduled. Any repair or maintenance performed will be documented in writing at the time of the repair and included in the annual letter report. 
CAP - CAU 151

Section: Post-Closure Plan

Revision: 0

Date: March 2007

THIS PAGE INTENTIONALLY LEFT BLANK 


\subsection{REFERENCES}

Bechtel Nevada. 2000a. Organization Instruction OI-2152.100, "Sample Chain of Custody." Las Vegas, NV.

Bechtel Nevada. 2000b. Organization Instruction OI-2152.108, “Soil Sampling.” Las Vegas, NV.

Bechtel Nevada. 2004. Organization Instruction OI-2151.303, "Validation of Radiological and Chemical Laboratory Data.” Las Vegas, NV.

Bechtel Nevada. 2005a. Company Directive CD-0442.010, “Waste Management.” Las Vegas, NV.

Bechtel Nevada, 2005b. Organization Instruction OI-2154.120, "Soil, Waste, and Water Sampling for Characterization and Compliance.” Las Vegas, NV.

Bechtel Nevada. 2005c Organization Instruction OI-2154.459, “Inorganic Data Verification and Validation.” Las Vegas, NV.

Bechtel Nevada. 2006. Company Directive CD-0442.006, "Hazardous Waste Management.” Las Vegas, NV.

BN, see Bechtel Nevada.

DOE, see U.S. Department of Energy.

EPA, see U.S. Environmental Protection Agency.

Federal Facility Agreement and Consent Order. 1996 (as amended). Agreed to by the State of Nevada, the U.S. Department of Energy, and the U.S. Department of Defense.

FFACO, see Federal Facility Agreement and Consent Order.

NNSA/NSO, see U.S. Department of Energy, National Nuclear Security Administration Nevada Site Office.

NNSA/NV, see U.S. Department of Energy, National Nuclear Security Administration Nevada Operations Office.

NSTec, see National Security Technologies, LLC.

U.S. Department of Energy. 1997. Environmental Measurements Laboratory Procedures Manual, HASL-300, $28^{\text {th }}$ Ed., Vol. 1. New York, NY.

U.S. Department of Energy, National Nuclear Security Administration Nevada Operations Office. 2002. Industrial Sites Quality Assurance Project Plan, Nevada Test Site, Nevada, Revision 3, DOE/NV--372. Las Vegas, NV. 
U.S. Department of Energy, National Nuclear Security Administration Nevada Site Office. 2004. Corrective Action Investigation Plan for Corrective Action Unit 151: Septic Systems and Discharge Area, Nevada Test Site, Nevada, DOE/NV--981, Las Vegas, NV.

U.S. Department of Energy, National Nuclear Security Administration Nevada Site Office. 2006. Corrective Action Decision Document for Corrective Action Unit 151: Septic Systems and Discharge Area, Nevada Test Site, Nevada, DOE/NV--1123, Las Vegas, NV.

U.S. Department of Energy, Nevada Operations Office. 2004. NV/YMP Radiological Control Manual, DOE/NV/11718--079-REV 5, Las Vegas, NV.

U.S. Environmental Protection Agency. 1996. Test Methods for Evaluating Solid Waste Physical/Chemical Methods, SW-846, Third Edition. Washington, D.C.

U.S. Environmental Protection Agency. 2006a. Data Quality Assessment: A Reviewer's Guide, QA/G-9R. Washington, D.C.

U.S. Environmental Protection Agency. 2006b. Systematic Planning: A Case Study for Hazardous Waste Site Investigations, QA/CS-1. Washington, D.C.

National Security Technologies, LLC. 2006a Form-0732 “Analytical Laboratory Service Request and Chain of Custody Report.” Las Vegas, NV.

National Security Technologies, LLC. 2006b Organization Procedure OP-2151.304, "Radiological Waste Tracking, Handling, and Management at the NTS." Las Vegas, NV. 


\section{APPENDIX A.1 \\ ENGINEERING SPECIFICATIONS AND DRAWINGS}

NOTE: Engineering specifications and drawings are not required for closure of CAU 151. This Appendix is included here as required by the approved Federal Facility Agreement and Consent Order outline for a Corrective Action Plan. 
CAP - CAU 151

Section: Appendix A.1

Revision: 0

Date: March 2007

THIS PAGE INTENTIONALLY LEFT BLANK

A.1-2 


\section{APPENDIX A.2}

\section{SAMPLING AND ANALYSIS PLAN}

NOTE: Sufficient details on the type, number, and location of verification samples to be collected to verify site closure activities have been provided in Sections 2.1.2 and 2.4 of this document. Additionally, sufficient details on waste characterization samples to be collected have been provided in Section 2.1 and 2.4. This Appendix is included here as required by the approved Federal Facility Agreement and Consent Order outline for a Corrective Action Plan. 
CAP - CAU 151

Section: Appendix A.2

Revision: 0

Date: March 2007

THIS PAGE INTENTIONALLY LEFT BLANK

A.2-2 
CAP - CAU 151

Section: Appendix A.3

Revision: 0

Date: March 2007

\section{APPENDIX A.3}

\section{PROJECT ORGANIZATION}


CAP - CAU 151

Section: Appendix A.3

Revision: 0

Date: March 2007

THIS PAGE INTENTIONALLY LEFT BLANK

A.3-2 
For this project, the U.S. Department of Energy, National Nuclear Security Administration Nevada Site Office (NNSA/NSO) points of contact are as follows:

NNSA/NSO Federal Industrial Sites Sub-Project Director (Acting): Peter A. Sanders Telephone Number: (702) 295-1037

NNSA/NSO Task Manager: Sabine Curtis

Telephone Number: (702) 295-0542

The identification of the project Health and Safety Officer and the Quality Assurance Officer can be found in the appropriate plan. However, personnel are subject to change and it is suggested that the appropriate U.S. Department of Energy Project Manager be contacted for further information. The Task Manager will be identified in the Federal Facility Agreement and Consent Order Monthly Activity Report prior to the start of field activities. 
CAP - CAU 151

Section: Appendix A.3

Revision: 0

Date: March 2007

THIS PAGE INTENTIONALLY LEFT BLANK 
CAP - CAU 151

Section: Library Distribution List

Revision: 0

Date: March 2007

\section{LIBRARY DISTRIBUTION LIST}


CAP - CAU 151

Section: Library Distribution List

Revision: 0

Date: March 2007

THIS PAGE INTENTIONALLY LEFT BLANK 
U.S. Department of Energy

National Nuclear Security Administration

Nevada Site Office

Technical Library

P.O. Box 98518, M/S 505

Las Vegas, NV 89193-8518

U.S. Department of Energy

Office of Scientific and Technical Information

P.O. Box 62

Oak Ridge, TN 37831-0062

Southern Nevada Public Reading Facility

c/o Nuclear Testing Archive

P.O. Box 98521, M/S 400

Las Vegas, NV 89193-8521

Manager, Northern Nevada FFACO

Public Reading Facility

c/o Nevada State Library \& Archives

Carson City, NV 89701-4285
1 (Uncontrolled, electronic copy)

1 (Uncontrolled, electronic copy)

2 (Uncontrolled, electronic copies)

1 (Uncontrolled, electronic copy) 
CAP - CAU 151

Section: Library Distribution List

Revision: 0

Date: March 2007

THIS PAGE INTENTIONALLY LEFT BLANK 